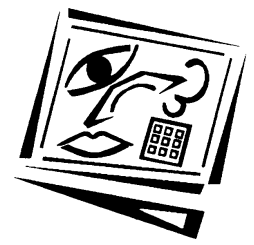

\title{
Beyond lecture capture: What teaching staff want from web-based lecture technologies
}

\author{
Lisa Germany \\ Swinburne University of Technology
}

\begin{abstract}
For the past decade, the primary use of recordings in higher education has been to make live lectures available to students for review (lecture capture). However, with the rise of podcasting and the increased focus on interaction as a means to engage students, current web-based lecture technologies (WBLT) are capable of much more than simply recording and distributing a live lecture. This study aimed to discover what teaching staff are currently doing, and what they would like to be doing with WBLT for learning and teaching. Data were drawn from initial focus groups conducted with 10 academic teaching staff at Swinburne University of Technology, as well as an online survey that was distributed to all Swinburne staff with a lecture capture account. Three key requirements for a university-wide WBLT system were identified: flexibility in where and when recordings can be made, flexibility in control over those recordings, and the desire to be able to interact with the recordings and incorporate them as an integral part of the course. These findings indicate that teaching staff want to innovate in their use of recordings and need to be supported to do so through the adoption of an appropriate recording solution.
\end{abstract}

\section{Introduction}

This paper asserts that any centralised web-based lecture technologies (WBLT) system adopted by a university must be flexible and interactive, enabling teaching staff to innovate in their use of recordings for learning and teaching, while remaining accessible to staff who are less technically inclined. Until now, the capture of live lectures - the traditional form of teaching in most universities - has been the primary driver for universities to implement a centralised WBLT system. There are many legitimate arguments to support this practice and many studies have shown that students have embraced the opportunity and utilised the recordings for a range of purposes (e.g. Copley, 2007; Preston, Phillips, Gosper, McNeill, Woo \& Green, 2010).

However, there is now growing evidence that teaching staff are wanting to move beyond simple lecture capture and are starting to explore other uses of WBLT for learning and teaching. In a review of the literature surrounding the use audio podcasts (essentially audio recordings) in K-12 and higher education, Hew (2009) identified four key categories of podcasts that can broadly be described as: (1) lecture podcasts - the recording of a live lecture, (2) supplementary podcasts - recordings made to provide additional information outside of the lecture, (3) podcasts created by students as part of their course, and (4) podcasts made by third parties that are relevant to the course. This work extended and generalised the taxonomy of podcast use for language learning previously developed by Rossell-Aguilar (2007). 
In a separate review of podcasting in higher education, McGarr (2009) suggested that the different types of recordings now being created by teaching staff form a continuum. Substitutional recordings (Hew's "lecture podcasts") occupy one end of the continuum, which then proceeds through supplementary recordings (Hew's "supplementary podcasts" and "third-party material") to creative recordings at the other end ("student podcasts" in Hew's taxonomy).

These reviews indicate that the ability to record live lectures is no longer sufficient for a university-wide WBLT system, as staff find different ways to utilise recordings to enhance the student learning experience. Leading lecture capture vendors have already taken note of this trend and now provide as part of their enterprise systems the ability to create recordings from any computer, not just those in dedicated lecture theatres with specialised equipment. This means that teaching staff and students are able to utilise the one system to create all types of recordings across Hew's (2009) categories and McGarr's (2009) continuum.

Some vendors are also starting to offer a more interactive lecture capture experience for students. In a study sponsored by one of these vendors, Wainhouse Research proposed that personalisation would be "the next big thing" for WBLT (Greenberg \& Nilssen, 2010). They cite the ability to set private or public bookmarks, make private or public annotations, and for interaction through and with the recording as new, significant enhancements to the student and instructor experience of lecture capture.

This personalisation of the lecture experience and the desire to make it more interactive is certainly not a new idea and was suggested as far back as 1999 by Truong, Abowd and Brotherton (1999). More recently, several papers have reported on the development of in-house technologies (Steimle, Brdiczka \& Mühlhäuser, 2009; Su, Yang, Hwang \& Zhang, 2010; Mu, 2010) and commercially available technologies (Kam, Wang, Iles, Tse, Chiu, Glaser, Tarshish \& Canny, 2005; Berque, 2006) that allow for the collaborative annotation of classroom slides and videos. Some of these new technologies offer the ability to record the real-time interactions for later review, providing an impetus for lecture capture vendors to incorporate personalisation and interactivity into their products.

This study takes a different approach to WBLT investigations by asking teaching staff at a single university what they currently do, and what they would like to do with WBLT for learning and teaching. Based on this data, the paper provides three key recommendations for universities planning to upgrade or invest in a new WBLT system.

\section{The Swinburne context}

The results presented in this paper were obtained from group discussions and the surveying of teaching staff at one university. Given that opinions expressed by individuals are often experience-based and that the institutional context will have played a role in the study, the following is a brief summary of how WBLT is implemented at Swinburne.

Swinburne University of Technology is based in Melbourne, Australia, and is a dualsector institute offering both vocational and higher education qualifications. All face to face courses have an online component that is delivered primarily through the 
university's learning management system. However, Swinburne also offers an extensive range of fully-online courses and will significantly grow this online cohort in the next few years through strategic partnerships.

Swinburne was one of the first universities in Australia to adopt wide-scale lecture capture and has had a central recording system (Lectopia, 2012) in place since mid-2004. All lecture theatres and many classrooms have the system installed, but there is no university-supported WBLT capability outside of these venues. This means that staff need to support themselves to make recordings from a computer lab, a tutorial room or their private office.

Swinburne has adopted an "opt-in" policy where sessions are not recorded unless teaching staff choose to do so. If a recording is to be made, teaching staff must request an account for the recording system and book their sessions through an online form at least two days in advance. There is currently no option for ad-hoc recordings.

In the venue, the recording starts and stops automatically according to the prescheduled booking. An "on air" light indicates when the recording is active, and teaching staff have the ability to pause and resume the recording as they wish. Staff can also stop the recording ahead of time, however, once the recording is stopped, they cannot restart it.

\section{Method}

The primary purpose of this study was to investigate two research questions: (1) what teaching staff currently do, and (2) what teaching staff would like to be able to do with WBLT for learning and teaching. This information was used to inform the project to upgrade the lecture capture system at Swinburne University of Technology to ensure it would support the needs teaching staff and allow them to innovate in their future use of recordings.

The study was carried out between November 2010 and February 2011. Ethics approval was obtained for a study in two phases: Phase 1 - discussion and preliminary questionnaire with a small focus group of higher education teaching staff, and Phase 2 - an online questionnaire distributed to all teaching staff (higher education and vocational) with a user account for Swinburne's current recording system.

\section{Phase 1 - Focus group discussion and preliminary questionnaire}

Two volunteers from each of Swinburne's six Melbourne-based higher education Faculties (12 participants in total) were sought to join the focus group discussion. These self-selected academic staff tended to be heavy users of the current system or those who were already exploring beyond the limitations of the system installed at the University.

There were two focus groups to accommodate the schedules of the participants with 4 and 6 participants respectively. Unfortunately 2 of the 12 participants did not attend as scheduled and it was also not possible to ensure that each Faculty had a representative in each focus group (i.e. there were some instances where both representatives from the one Faculty were in the same group). The focus groups followed the same format of a 55 minute, semi-structured discussion around the two key research questions. 
Participants were emailed these broad topics in advance and encouraged to consult with colleagues within their Faculty so they could present a wider view, not just their own, in the focus group.

In addition to the broader discussion, the last five minutes of each focus group was dedicated to a paper-based preliminary questionnaire (Appendix A) that asked participants to rate the importance of features now available in different WBLT systems. This questionnaire was included as part of the focus groups as it was considered highly likely that many academic teaching staff would not be familiar with the different features now available in enterprise systems and would find it difficult to think beyond their own experience (even alternate desktop applications like ProfCast and Camtasia do not incorporate all the features now enabled in enterprise systems). By presenting participants with real possibilities of the types of things that are now technically feasible, it was possible to push them beyond their current experiences and gather additional information about what they would like to be able to do with recordings for learning and teaching. The questionnaire was not handed out until the end of the focus group, in order to limit the influence this may have had on the initial discussion that was based on current user experiences.

The features listed in the preliminary questionnaire were determined by the investigator from online product descriptions and through demonstrations of the products by the vendors. It was felt unlikely that the focus group participants would have had direct experience with all of these features, so their responses to the preliminary questionnaire were in part "perceived importance" based on the descriptions given. The 5-point Likert-scale ran from "not important" to "very important" and participants completed the questionnaire before leaving the room.

\section{Phase 2 - online questionnaire}

Once the discussion and preliminary questionnaires from the focus groups were analysed, an online questionnaire was developed for broader distribution. This questionnaire drew heavily on the preliminary questionnaire given to focus group participants and included the same 5-point Likert-scale, but adjusted the wording for clarity and included additional items identified through the focus group discussions.

An explanation of the study and a link to the online questionnaire were emailed to the 457 staff with an account for Swinburne's current lecture capture system. Targeting this group tried to ensure that responses would be based on at least some experience of using the system currently in place at Swinburne. However, it is possible that some account holders were administrative staff who make bookings on behalf of teaching staff, and it is also likely that staff who bought their own software to make recordings were unfortunately excluded.

\section{Data analysis}

Focus group discussions were recorded, transcribed and themes within each topic identified. Descriptive statistics were calculated from the broader online questionnaire using the SPSS software package. The qualitative data from the focus groups and the data from the online questionnaire were used to derive the final recommendations in this paper. Data from the preliminary questionnaire were not incorporated into the final analysis as the wording of some items had changed. 


\section{Results}

The results presented in Table 1 and Table 2 are from the more broadly distributed online questionnaire. Out of the 457 staff with a lecture-capture account, a total of 96 completed the online questionnaire, representing $21 \%$ of account holders. Results from the preliminary questionnaire are not included here so as not to confuse the analysis (questions were worded slightly differently between the two questionnaires). Qualitative findings from the focus group participants are, however, included below.

The results are presented according to the two primary research questions: 1) What teaching staff are currently doing, and 2) What teaching staff would like to be doing with WBLT for learning and teaching.

\section{What teaching staff are currently doing with recordings}

Table 1 shows the number and percentage of respondents to the online survey who identified with specific uses of WBLT. Note that they could choose more than one option.

Table 1: Number and percentage of respondents using WBLT for the uses identified $(\mathrm{N}=96)$

\begin{tabular}{|l|c|c|}
\hline \multicolumn{1}{|c|}{ Question } & $\begin{array}{c}\text { Number of } \\
\text { respondents }\end{array}$ & $\begin{array}{c}\% \\
\text { respondents }\end{array}$ \\
\hline I record my live lectures & 72 & $75 \%$ \\
\hline $\begin{array}{l}\text { I record short lecture summaries or supplementary material } \\
\text { outside of lectures }\end{array}$ & 15 & $16 \%$ \\
\hline I record guest speakers & 28 & $29 \%$ \\
\hline I record announcements and instructions & 2 & $2 \%$ \\
\hline I get my students to make recordings as part of their learning & 7 & $7 \%$ \\
\hline $\begin{array}{l}\text { I record my students for self or peer-evaluation to improve } \\
\text { communication skills }\end{array}$ & 7 & $7 \%$ \\
\hline I record myself to improve communication skills & 10 & $10 \%$ \\
\hline
\end{tabular}

The most common uses of WBLT at Swinburne are to capture live lectures and record guest speakers. This is not surprising, given that Swinburne's current recording facilities are located in lecture theatres and classrooms that are heavily booked during the semester.

What is surprising is the number of staff who record short lecture summaries or supplementary material outside of lectures, as there is no Swinburne-supported desktop application that staff can use to make recordings in their office. Unfortunately the survey didn't gather any information on how staff are creating these recordings, but 4 out of the 10 focus group participants talked about purchasing their own software to record such supplementary material for their students.

I do lecturettes ... I've bought a piece of software called Profcast

Camtasia ... for study material to put into the online material whenever there is a difficult concept

\section{What teaching staff want to be able to do with recordings}

In approaching the second research question about how staff want to be able to use WBLT for learning and teaching, focus group participants were encouraged to think 
beyond lecture capture, to identify what other types of recordings they would like to make and what functionalities might be required of a recording system in order for that to happen. Given no prompts as to what was possible, this discussion proceeded as expected - drawing primarily on what participants knew, had seen or had already experienced in using WBLT. It therefore tended to focus on how the current Swinburne system could be improved, highlighting the immediate concerns teaching staff have within the Swinburne context.

One very strong theme emerged from these discussions - the need for flexibility. Flexibility in the location of where a recording could be created was particularly important to participants, who cited the ability to record in any teaching space and in their office as key requirements.

make it really easy to record outside of the lecture theatre - it doesn't seem to be so easy without having to buy your own software

I want to be able to record offline

record - anywhere, anytime, no booking

Flexibility to control the recording at the time of creation was also important to focus group participants, as many wanted to make impromptu recordings, start and stop the recording as they wished, and have the ability to edit the recording before making it available to their students.

had a student give an impromptu demonstration ... and as he was doing it, I thought 'it would be great if we can capture this right now'. It would have been good to hit a button, press record.

I want the ability to turn it on and off. Or edit it after.

However, it was clear from those participants who consulted with colleagues in their Faculty, that this desire was not universal, with some teaching staff just wanting to walk in and walk out without having to touch anything.

people want it just to happen ... don't even want to press a button .. [but] there's another group who want much better control

A secondary theme also emerged from the focus group discussions - the ability to interact with students and have that interaction captured. Two focus group participants raised the idea of having a roving microphone so that student comments and discussion could be recorded alongside whatever the lecturer was saying while several participants concurred that the ability to gather feedback from students would be very helpful. Most participants were familiar with the use of audience response systems to interact with students, but one participant also raised the idea of asynchronous interaction, something that is now enabled by certain lecture capture vendors:

I think that sometimes it is much better when you just get the lecture, and then if students want to pool their knowledge about what was covered - they can do that in comment or through some other thing

Table 2 lists the functionalities proposed in the broader online questionnaire and the mean and standard deviation for each. The overarching question was "How would 
you rate the following functionalities in a recording system on the following scale: 1 (not important), 2 (of little importance), 3 (neutral), 4 (somewhat important), 5 (very important)?"

Table 2: Number and percentage of respondents selecting the importance of each functionality posed in the online questionnaire $(\mathrm{N}=96)$

\begin{tabular}{|c|c|c|c|c|c|c|c|c|}
\hline \multicolumn{2}{|r|}{ Functionalities } & $\begin{array}{c}1 \\
(\mathrm{f} \%)\end{array}$ & $\begin{array}{c}2 \\
(\mathrm{f} \%)\end{array}$ & $\begin{array}{c}3 \\
(\mathrm{f} \%)\end{array}$ & $\begin{array}{c}4 \\
(\mathrm{f} \%)\end{array}$ & $\begin{array}{c}5 \\
(\mathrm{f} \%)\end{array}$ & Mean & $\begin{array}{l}\text { Std } \\
\text { dev }\end{array}$ \\
\hline 1 & $\begin{array}{l}\text { See whatever is presented on ONE of } \\
\text { the Lecture Theatre screens in the } \\
\text { recording (+ audio) }\end{array}$ & $\begin{array}{c}4 \\
(4.2)\end{array}$ & $\begin{array}{c}2 \\
(2.1)\end{array}$ & $\begin{array}{c}4 \\
(4.2)\end{array}$ & $\begin{array}{c}20 \\
(20.8)\end{array}$ & $\begin{array}{c}66 \\
(68.8)\end{array}$ & 4.47 & 0.98 \\
\hline 2 & $\begin{array}{l}\text { See whatever is shown on BOTH of the } \\
\text { Lecture Theatre screens in the recording } \\
\text { (+ audio) }\end{array}$ & $\begin{array}{c}18 \\
(18.8)\end{array}$ & $\begin{array}{c}13 \\
(13.5)\end{array}$ & $\begin{array}{c}24 \\
(25.0)\end{array}$ & $\begin{array}{c}28 \\
(29.2)\end{array}$ & $\begin{array}{c}13 \\
(13.5)\end{array}$ & 3.05 & 1.31 \\
\hline 3 & $\begin{array}{l}\text { See the presenter's "talking head" in the } \\
\text { recording (+ audio) }\end{array}$ & $\begin{array}{c}20 \\
(20.8)\end{array}$ & $\begin{array}{c}11 \\
(11.5)\end{array}$ & $\begin{array}{c}22 \\
(22.9)\end{array}$ & $\begin{array}{c}27 \\
(28.1)\end{array}$ & $\begin{array}{c}16 \\
(16.7)\end{array}$ & 3.08 & 1.38 \\
\hline 4 & $\begin{array}{l}\text { See whatever is being presented on } \\
\text { ONE of the lecture theatre screens along } \\
\text { with the presenter's "talking head" in } \\
\text { the recording (+ audio) }\end{array}$ & $\begin{array}{c}17 \\
(17.7)\end{array}$ & $\begin{array}{c}8 \\
(8.3)\end{array}$ & $\begin{array}{c}26 \\
(27.1)\end{array}$ & $\begin{array}{c}26 \\
(27.1)\end{array}$ & $\begin{array}{c}19 \\
(19.8)\end{array}$ & 3.22 & 1.35 \\
\hline 5 & $\begin{array}{l}\text { Quickly and easily annotate / scribble } \\
\text { over the top of whatever you are } \\
\text { showing on the screen and record that }\end{array}$ & $\begin{array}{c}11 \\
(11.5)\end{array}$ & $\begin{array}{c}7 \\
(7.3)\end{array}$ & $\begin{array}{c}18 \\
(18.8)\end{array}$ & $\begin{array}{c}34 \\
(35.4)\end{array}$ & $\begin{array}{c}26 \\
(27.1)\end{array}$ & 3.59 & 1.28 \\
\hline 6 & $\begin{array}{l}\text { Broadcast/stream the session (e.g. to } \\
\text { another room) while delivering/ } \\
\text { recording it }\end{array}$ & $\begin{array}{c}25 \\
(26.0)\end{array}$ & $\begin{array}{c}19 \\
(19.8)\end{array}$ & $\begin{array}{c}27 \\
(28.1)\end{array}$ & $\begin{array}{c}22 \\
(22.9)\end{array}$ & $\begin{array}{c}3 \\
(3.1)\end{array}$ & 2.57 & 1.19 \\
\hline 7 & $\begin{array}{l}\text { Capture student discussion in the } \\
\text { recording (e.g. with roving microphone) }\end{array}$ & $\begin{array}{c}8 \\
(8.3) \\
\end{array}$ & $\begin{array}{c}12 \\
(12.5)\end{array}$ & $\begin{array}{c}18 \\
(18.8)\end{array}$ & $\begin{array}{c}35 \\
(36.5)\end{array}$ & $\begin{array}{c}23 \\
(24.0) \\
\end{array}$ & 3.55 & 1.22 \\
\hline 8 & $\begin{array}{l}\text { Visual indicator that the microphone is } \\
\text { working and the volume level of the } \\
\text { microphone }\end{array}$ & $\begin{array}{c}1 \\
(1.0)\end{array}$ & $\begin{array}{c}1 \\
(1.0)\end{array}$ & $\begin{array}{c}5 \\
(5.3)\end{array}$ & $\begin{array}{c}22 \\
(22.9)\end{array}$ & $\begin{array}{c}67 \\
(69.8)\end{array}$ & 4.59 & 0.73 \\
\hline 9 & $\begin{array}{l}\text { Visual indicator (e.g. an "on air" light) } \\
\text { that you are being recorded }\end{array}$ & $\begin{array}{c}1 \\
(1.0) \\
\end{array}$ & $\begin{array}{c}2 \\
(2.1) \\
\end{array}$ & $\begin{array}{c}1 \\
(1.0) \\
\end{array}$ & $\begin{array}{c}15 \\
(15.6)\end{array}$ & $\begin{array}{c}77 \\
(80.2) \\
\end{array}$ & 4.71 & 0.69 \\
\hline 10 & $\begin{array}{l}\text { Make recordings from your office, } \\
\text { home or out in the field }\end{array}$ & $\begin{array}{c}10 \\
(10.4)\end{array}$ & $\begin{array}{c}4 \\
(4.2)\end{array}$ & $\begin{array}{c}18 \\
(18.8)\end{array}$ & $\begin{array}{c}26 \\
(27.1)\end{array}$ & $\begin{array}{c}38 \\
(39.6)\end{array}$ & 3.81 & 1.29 \\
\hline 11 & $\begin{array}{l}\text { Students can use the same system to } \\
\text { create their own recordings }\end{array}$ & $\begin{array}{c}17 \\
(17.7)\end{array}$ & $\begin{array}{c}9 \\
(9.4)\end{array}$ & $\begin{array}{c}34 \\
(35.4)\end{array}$ & $\begin{array}{c}27 \\
(28.1)\end{array}$ & $\begin{array}{c}9 \\
(9.4) \\
\end{array}$ & 3.02 & 1.21 \\
\hline 12 & $\begin{array}{l}\text { Schedule recordings in advance. To be } \\
\text { able to simply walk in and start talking. }\end{array}$ & $\begin{array}{c}7 \\
(7.3)\end{array}$ & $\begin{array}{c}5 \\
(5.2)\end{array}$ & $\begin{array}{c}15 \\
(15.6)\end{array}$ & $\begin{array}{c}29 \\
(30.2)\end{array}$ & $\begin{array}{c}40 \\
(41.7)\end{array}$ & 3.94 & 1.20 \\
\hline 13 & $\begin{array}{l}\text { Start and stop the recording when you } \\
\text { are ready. To not have to schedule in } \\
\text { advance. }\end{array}$ & $\begin{array}{c}2 \\
(2.1)\end{array}$ & $\begin{array}{c}3 \\
(3.1)\end{array}$ & $\begin{array}{c}11 \\
(11.5)\end{array}$ & $\begin{array}{c}27 \\
(28.1)\end{array}$ & $\begin{array}{c}53 \\
(55.2)\end{array}$ & 4.31 & 0.94 \\
\hline 14 & $\begin{array}{l}\text { Pause and resume the recording when } \\
\text { you want }\end{array}$ & $\begin{array}{c}0 \\
(0.0)\end{array}$ & $\begin{array}{c}1 \\
(1.0)\end{array}$ & $\begin{array}{c}5 \\
(5.2)\end{array}$ & $\begin{array}{c}16 \\
(16.7)\end{array}$ & $\begin{array}{c}74 \\
(77.1)\end{array}$ & 4.69 & 0.62 \\
\hline 15 & $\begin{array}{l}\text { Easily chop off the beginning and } \\
\text { ending of the recording before making } \\
\text { it available to students }\end{array}$ & $\begin{array}{c}3 \\
(3.1)\end{array}$ & $\begin{array}{c}2 \\
(2.1)\end{array}$ & $\begin{array}{c}10 \\
(10.4)\end{array}$ & $\begin{array}{c}33 \\
(34.4)\end{array}$ & $\begin{array}{c}48 \\
(50.0)\end{array}$ & 4.26 & 0.95 \\
\hline 16 & $\begin{array}{l}\text { Easily edit any part of the recording } \\
\text { before making it available to students }\end{array}$ & $\begin{array}{c}3 \\
(3.1)\end{array}$ & $\begin{array}{c}4 \\
(4.2)\end{array}$ & $\begin{array}{c}10 \\
(10.4)\end{array}$ & $\begin{array}{c}29 \\
(30.2)\end{array}$ & $\begin{array}{c}50 \\
(52.1)\end{array}$ & 4.24 & 1.01 \\
\hline 17 & $\begin{array}{l}\text { Easily chop up a long recording into } \\
\text { certain key, shorter recordings }\end{array}$ & $\begin{array}{c}5 \\
(5.2)\end{array}$ & $\begin{array}{c}6 \\
(6.3)\end{array}$ & $\begin{array}{c}10 \\
(10.4)\end{array}$ & $\begin{array}{c}37 \\
(38.5)\end{array}$ & $\begin{array}{c}38 \\
(39.6)\end{array}$ & 4.01 & 1.11 \\
\hline 18 & $\begin{array}{l}\text { Set dates after/between which the } \\
\text { recording is available to students. Not } \\
\text { necessarily make it available } \\
\text { immediately }\end{array}$ & $\begin{array}{c}6 \\
(6.3)\end{array}$ & $\begin{array}{c}8 \\
(8.3)\end{array}$ & $\begin{array}{c}22 \\
(22.9)\end{array}$ & $\begin{array}{c}37 \\
(38.5)\end{array}$ & $\begin{array}{c}23 \\
(24.0)\end{array}$ & 3.66 & 1.12 \\
\hline
\end{tabular}




\begin{tabular}{|c|c|c|c|c|c|c|c|c|}
\hline 19 & $\begin{array}{l}\text { Easily integrated with the learning } \\
\text { management system }\end{array}$ & $\begin{array}{c}1 \\
(1.0)\end{array}$ & $\begin{array}{c}1 \\
(1.0)\end{array}$ & $\begin{array}{c}6 \\
(6.3)\end{array}$ & $\begin{array}{c}16 \\
(16.7)\end{array}$ & $\begin{array}{c}72 \\
(75.0) \\
\end{array}$ & 4.63 & 0.74 \\
\hline 20 & $\begin{array}{l}\text { Easily integrated with mobile devices } \\
\text { (e.g. watch on different mobile } \\
\text { platforms, notification of availability of } \\
\text { new recordings) }\end{array}$ & $\begin{array}{c}4 \\
(4.2)\end{array}$ & $\begin{array}{c}2 \\
(2.1)\end{array}$ & $\begin{array}{c}14 \\
(14.6)\end{array}$ & $\begin{array}{c}39 \\
(40.6)\end{array}$ & $\begin{array}{c}37 \\
(38.5)\end{array}$ & 4.07 & 1.00 \\
\hline 21 & $\begin{array}{l}\text { Attach supplementary documentation } \\
\text { (e.g. PDF file) to the recording }\end{array}$ & $\begin{array}{c}6 \\
(6.3) \\
\end{array}$ & $\begin{array}{c}7 \\
(7.3)\end{array}$ & $\begin{array}{c}13 \\
(13.5)\end{array}$ & $\begin{array}{c}36 \\
(37.5)\end{array}$ & $\begin{array}{c}34 \\
(35.4)\end{array}$ & 3.88 & 1.16 \\
\hline 22 & $\begin{array}{l}\text { Have recordings automatically } \\
\text { chapterised based on new slides (or } \\
\text { other objects) appearing on the screen. }\end{array}$ & $\begin{array}{c}11 \\
(11.5)\end{array}$ & $\begin{array}{c}8 \\
(8.3)\end{array}$ & $\begin{array}{c}22 \\
(22.9)\end{array}$ & $\begin{array}{c}35 \\
(36.5)\end{array}$ & $\begin{array}{c}20 \\
(20.8)\end{array}$ & 3.47 & 1.24 \\
\hline 23 & $\begin{array}{l}\text { Search recordings for words in any of } \\
\text { the text that appears on the screen }\end{array}$ & $\begin{array}{c}13 \\
(13.5)\end{array}$ & $\begin{array}{c}12 \\
(12.5)\end{array}$ & $\begin{array}{c}28 \\
(29.2)\end{array}$ & $\begin{array}{c}30 \\
(31.3)\end{array}$ & $\begin{array}{c}13 \\
(13.5)\end{array}$ & 3.19 & 1.23 \\
\hline 24 & $\begin{array}{l}\text { Set bookmarks in the recording to } \\
\text { highlight key points to the entire class }\end{array}$ & $\begin{array}{c}11 \\
(11.5)\end{array}$ & $\begin{array}{c}8 \\
(8.3)\end{array}$ & $\begin{array}{c}17 \\
(17.7)\end{array}$ & $\begin{array}{c}40 \\
(41.7)\end{array}$ & $\begin{array}{c}20 \\
(20.8)\end{array}$ & 3.52 & 1.24 \\
\hline 25 & $\begin{array}{l}\text { See bookmarks set by students that } \\
\text { show what they consider to be "import- } \\
\text { ant", "unclear" or where they have made } \\
\text { a "comment" on the recording }\end{array}$ & $\begin{array}{c}9 \\
(9.4)\end{array}$ & $\begin{array}{c}11 \\
(11.5)\end{array}$ & $\begin{array}{c}31 \\
(32.3)\end{array}$ & $\begin{array}{c}30 \\
(31.3)\end{array}$ & $\begin{array}{c}15 \\
(15.6)\end{array}$ & 3.32 & 1.16 \\
\hline 26 & $\begin{array}{l}\text { Easily pinpoint a moment in time in a } \\
\text { recording and push that to others so } \\
\text { that it can be discussed further (e.g. in a } \\
\text { linked discussion forum). }\end{array}$ & $\begin{array}{c}8 \\
(8.3)\end{array}$ & $\begin{array}{c}11 \\
(11.5)\end{array}$ & $\begin{array}{c}25 \\
(26.0)\end{array}$ & $\begin{array}{c}35 \\
(36.5)\end{array}$ & $\begin{array}{c}17 \\
(17.7)\end{array}$ & 3.44 & 1.16 \\
\hline 27 & $\begin{array}{l}\text { Play back the recording at different } \\
\text { speeds }(0.7 x \text { to } 2 x)\end{array}$ & $\begin{array}{c}12 \\
(12.5)\end{array}$ & $\begin{array}{c}3 \\
(3.1)\end{array}$ & $\begin{array}{c}34 \\
(35.4)\end{array}$ & $\begin{array}{c}34 \\
(35.4)\end{array}$ & $\begin{array}{c}13 \\
(13.5)\end{array}$ & 3.34 & 1.15 \\
\hline 28 & $\begin{array}{l}\text { Addition of close captioning text to } \\
\text { recordings }\end{array}$ & $\begin{array}{c}12 \\
(12.5)\end{array}$ & $\begin{array}{c}10 \\
(10.4)\end{array}$ & $\begin{array}{c}33 \\
(24.4)\end{array}$ & $\begin{array}{c}33 \\
(34.4)\end{array}$ & $\begin{array}{c}8 \\
(8.3)\end{array}$ & 3.16 & 1.13 \\
\hline 29 & $\begin{array}{l}\text { Print thumbnails of the slides (includ- } \\
\text { ing any annotations you have made) }\end{array}$ & $\begin{array}{c}13 \\
(13.5)\end{array}$ & $\begin{array}{c}8 \\
(8.3)\end{array}$ & $\begin{array}{c}32 \\
(33.3)\end{array}$ & $\begin{array}{c}29 \\
(30.2)\end{array}$ & $\begin{array}{c}14 \\
(14.6)\end{array}$ & 3.24 & 1.21 \\
\hline 30 & $\begin{array}{l}\text { Easily obtain usage statistics for } \\
\text { recordings }\end{array}$ & $\begin{array}{c}4 \\
(4.2) \\
\end{array}$ & $\begin{array}{c}3 \\
(3.1)\end{array}$ & $\begin{array}{c}8 \\
(8.3)\end{array}$ & $\begin{array}{c}39 \\
(40.6)\end{array}$ & $\begin{array}{c}42 \\
(43.8)\end{array}$ & 4.17 & 1.00 \\
\hline
\end{tabular}

The need for increased flexibility is also evident in the online survey responses, where the ability to make recordings from anywhere (Q10) was rated as either very or somewhat important by $67 \%$ of respondents. The need for flexibility in the control of recordings also came through, with $72 \%$ of respondents wanting the ability to schedule recordings in advance (Q12) and $83 \%$ wanting the ability to stop and start the recording when they were ready (Q13). This suggests that some respondents would prefer both options to be available and that they would determine which to utilise depending on the situation. Overwhelmingly, respondents wanted to be able to pause and resume the recording (Q14: $94 \%$ rated this as either very important or somewhat important) and $84 \%$ and $82 \%$ wanted the ability to quickly and easy edit the recording once it was made (Q15, 16 respectively).

When presented with the possibilities now available for interacting with the recording (Q23-26), 63\% of respondents felt that the ability for the instructor to set bookmarks within the recording to highlight key points for students was important. Fewer respondents $(47 \%)$ felt that the ability for students to tag parts of the recording (for example as "unclear" if they had trouble with the explanation given) was important, while $54 \%$ placed importance on the ability to link a discussion forum to certain parts of the recording. One possibility for the cautious interest in these measures is that many of the respondents to the online questionnaire were not technically inclined, and few (if any) of the respondents would have actually seen how this interactivity is enabled in current lecture capture systems. This is supported by the fact that a significant number of staff answered "neutral" (the middle answer) to these questions. 
It would have been interesting to explore whether staff interest increased if they had the opportunity to see how this interactivity can be implemented.

Finally, having easily accessible and easy to interpret usage statistics was highly sought by $84 \%$ of respondents (Q30). This supports the current interest in learning analytics and the inclusion of analytics in the Technology outlook for Australian tertiary education 2012-2017 (New Media Consortium \& Griffith University, 2012).

\section{Recommendations}

The results of this study confirm that the capture of live lectures is currently the most common use of WBLT at Swinburne. However, they also indicate that given the opportunity, many staff are looking to innovate and require a WBLT system that supports them in this endeavour. What follows are three recommendations for universities considering upgrading or investing in a new WBLT system.

\section{Recommendation 1: Enable both high quality integrated classroom capture in dedicated venues as well personal capture that can be used from any laptop or desktop.}

\section{Recommendation 2: Enable flexibility in control of recordings including the ability to start, stop and pause recordings and the ability to quickly edit the result before making it available to students.}

The ability to create recordings wherever and whenever is essential to the ability to innovate. Being tied to heavily booked lecture theatres with specialised equipment and having to schedule recordings several days in advance does nothing to promote creativity and innovation. Some Swinburne staff have already purchased their own software so that they can make recordings outside of dedicated lecture theatres and their innovations in the use of recordings for learning and teaching have been featured around the world through Swinburne's iTunes $U$ site.

In 2004, Duke University provided the ultimate in flexibility by distributing mobile devices (Apple iPods with the ability to record audio) to staff and first-year students (Belanger, 2005). Their extensive evaluation revealed five types of academic use for $i$ Pods, two of which pertain directly to the ability to make recordings: (1) the iPod was used in the classroom to record lectures, small group discussions and verbal feedback, and (2) the iPod was used to make recordings in the field including capturing field notes, interviews and environmental sounds.

Of these uses, traditional implementations of WBLT typically enable only the recording of lectures and, depending on the institution, this may be limited to specific venues and may need to be pre-scheduled. The remaining uses identified by Belanger (2005) and other uses that have been identified in this study (recording short lecture summaries, explanations of key concepts, announcements and instructions, and recording students for self- or peer-evaluation) are representative of innovations that may be facilitated if staff and students are given sufficient flexibility in their ability to create and edit recordings.

However, it is also clear from the focus group discussions conducted as part of this study that not all teaching staff are ready to innovate in their use of WBLT, and a university-wide system should not be so complicated that these staff are unable to use 
it. In the ideal scenario, teaching staff should have the opportunity to choose for themselves at any point in time, the ability to:

- Schedule in advance, or start and stop a recording on the fly;

- Use a fully-integrated system in a specified venue, or create ad-hoc recordings on a laptop or their desktop, add metadata and upload to the server;

- Edit, or not edit.

These options are all possible through the leading lecture capture vendors who now offer combinations of full classroom integration, and personal capture solutions with simple editing features. Recordings are processed in the same way and made available from the same place so it becomes a seamless experience for students to access lecture capture and supplementary material for their course. It is up to the individual institution to decide which options they wish to offer their staff and students and how they will integrate that into their infrastructure.

\section{Recommendation 3: Enable interactivity with finished recordings and informative review of statistics for staff}

Many teaching staff acknowledge that there are potential benefits to making recordings of lectures available for students, and if used as supplementary material and not to replace face to face lectures, WBLT has been shown to improve academic performance (Williams, Birch \& Hancock, 2012). However, there are still valid concerns about the possibility that some students will misuse these recordings and negatively impact their learning. In particular, and despite evidence to the contrary (Von Konsky, Ivins \& Gribble, 2009; Larkin, 2010), teaching staff fear that students will use the recordings as a substitute for engaging with the subject and staff, and believe that having the recordings available results in decreased attendance at lectures (Chang, 2007).

In addition, although much of the literature to date indicates that students embrace lecture capture and use the recordings for a variety of purposes (e.g. Preston et al. 2008). Taplin, Low and Brown (2011) argue that these past surveys may have oversampled students with a preference for lecture capture. Their paper presents a very different perspective, where $54 \%$ of students commented that it would make little or no difference to them if lectures were no longer recorded. Von Konsky, Ivins \& Gribble (2009) identified that "if students perceive that something is of value to their learning, they will tend to use it", so the study by Taplin, Low and Brown (2011) suggests that traditional lecture capture may be in need of some value adding if the majority of students are to engage with it.

One way to potentially overcome some of the concerns of teaching staff, and to add value to students, is to turn passive recordings that students may or may not use into interactive, embedded features of the course. Enabling interaction with the recording by allowing staff and students to bookmark key points and having integrated discussion forums provides new impetus for both parties to engage with what have traditionally been transmissive, self-help resources for motivated students.

Such interactivity enables peer-support amongst students, and also allows teaching staff to indirectly receive feedback on the lecture itself. Student comments, discussions and detailed usage patterns may highlight sections of the lecture that were unclear or in need of greater explanation. Through reflective practice, teaching staff may then 
choose to address these issues in the next face to face lecture, or utilise the recording system to create supplementary material that presents further information or explanations about those sections of the lecture.

This type of interactivity and usage analysis is now offered by a few of the leading lecture capture vendors. Although it is only relatively new, it should evolve with feedback from the community and transform recorded lectures into an integral part of the student learning experience. The data presented in this paper confirms that staff are interested in these interactive features and institutions should consider the added benefits derived from the ability to interact with the recordings when selecting a university-wide solution.

\section{Conclusion}

This study indicates that many teaching staff are looking to move beyond simple lecture capture and innovate in their use of WBLT for learning and teaching. In particular, they are looking for a system that is flexible in place and time, one which allows them to control the recording as it takes place, and one which offers interaction with and the ability to gather data from the finished recording.

However, it is important to keep in mind that the study was limited to a single university and further investigation is required to determine whether the results were overly influenced by the context of that institution. Conducting a similar study at other universities would determine whether similar themes emerge and provide a more robust set of recommendations for the sector. It would also be useful to conduct a study that focuses on what students want out of WBLT, given all the possibilities that are now available. This could further inform how institutions should be implementing WBLT for learning and teaching.

Any education institutions looking to upgrade or invest in a new WBLT system should consider these recommendations early in their planning.

\section{Acknowledgments}

This study was undertaken while the author was employed at Swinburne University of Technology. The author wishes to thank Dr Naumann Saeed for his assistance in collecting the data for this study. The author is also grateful to ESER, the Engineering and Science Education Research group at Swinburne University of Technology, for the support and feedback that contributed to the writing of this paper.

\section{References}

Belanger, Y. (2005). Duke University iPod first year experience final evaluation report. Durham, North Carolina, USA: Duke University. http:/ / cit.duke.edu/pdf/reports/ipod_initiative_04_05.pdf

Berque, D. (2006). An evaluation of a broad deployment of DyKnow software to support note taking and interaction using pen-based computers. Journal of Computing Sciences in Colleges, 21(6), 204-216. http: / / dl.acm.org/ft_gateway.cfm?id=1127469; also at

http: / / academic.depauw.edu / dberque/ ccsc_ne_2006_berque.pdf

Chang, S. (2007). Academic perceptions of the use of Lectopia: A University of Melbourne example. In ICT: Providing choices for learners and learning. Proceedings Ascilite Singapore 2007. http: / / www.ascilite.org.au/conferences/ singapore07/procs/chang.pdf 
Copley, J. (2007). Audio and video podcasts of lectures for campus-based students: Production and evaluation of student use. Innovations in Education and Teaching International, 44(4), 387399. http:/ / dx.doi.org/10.1080/14703290701602805

Greenberg, A. D. \& Nilssen, A. 2010. Personalisation: the next evolution in lecture capture technology. http:/ / pages.tegrity.com/personalization.html [viewed 2 Aug 2010]

Hew, K. F. (2009). Use of audio podcast in K-12 and higher education: A review of research topics and methodologies. Educational Technology Research and Develpoment, 57(3), 333-357. http: / / dx.doi.org/10.1007/ s11423-008-9108-3

Kam, M., Wang, J., Iles, A., Tse, E., Chiu, J., Glaser, D., Tarshish, O. \& Canny, J. (2005). Livenotes: A system for cooperative and augmented note-taking in lectures. Proceedings of the SIGCHI conference on Human factors in computing systems, 531-540. http: / / dx.doi.org/10.1145/1054972.1055046

Larkin, H. E. (2010). "But they won't come to lectures ..." The impact of audio recorded lectures on student experience and attendance. Australasian Journal of Educational Technology, 26(2), 238-249. http:/ / www.ascilite.org.au/ajet/ajet26/larkin.html

Lectopia (2012). http:/ / echo360.com/ [viewed 2 August 2012]

McGarr, O. (2009). A review of podcasting in higher education: Its influence on the traditional lecture. Australasian Journal of Educational Technology, 25(3), 309-321. http: / / www.ascilite.org.au/ajet/ajet25/mcgarr.html

$\mathrm{Mu}, \mathrm{X}$. (2010). Towards effective video annotation: An approach to automatically link notes with video content. Computers $\mathcal{E}$ Education, 55(4), 1752-1763 http: / / dx.doi.org/10.1016/j.compedu.2010.07.021

New Media Consortium and Griffith University (2012). Technology outlook for Australian tertiary education 2012-2017. http: / / www.nmc.org/publications / 2012-technology-outlook-au

Preston, G., Phillips, P., Gosper, M., McNeill, M., Woo, K. \& Green, D. (2010). Web-based lecture technologies: Highlighting the changing nature of teaching and learning. Australasian Journal of Educational Technology, 26(6), 717-728. http: / / www.ascilite.org.au/ajet/ajet26/preston.html

Rossell-Aguilar, F. (2007). Top of the pods-In search of a podcasting "podagogy" for language learning. Computer Assisted Language Learning, 20(5), 471-492. http: / / dx.doi.org/10.1080/09588220701746047

Steimle, J., Brdiczka, O. \& Mühlhäuser, M. (2009). Collaborative paper-based annotation of lecture slides. Educational Technology E Society, 12(4), 125-137. http:/ / www.ifets.info/journals/12_4/11.pdf

Su, A. Y. S., Yang, S. J. H., Hwang, W. \& Zhang, J. (2010). A Web 2.0-based collaborative annotation system for enhancing knowledge sharing in collaborative learning environments. Computers E Education, 55(2), 752-766. http:/ / dx.doi.org/10.1016/j.compedu.2010.03.008

Taplin, R. H., Low, L. H. \& Brown, A. M. (2011). Students' satisfaction and valuation of webbased lecture recording technologies. Australasian Journal of Educational Technology, 27(2), 175191. http:/ / www.ascilite.org.au/ajet/ajet27/taplin.html

Truong, K. N., Abowd, G. D. \& Brotherton, J. A. (1999). Personalizing the capture of public experience. In UIST '99: Proceedings of the 12th annual ACM symposium on user interface software and technology, 121-130. http:/ / dx.doi.org/10.1145/320719.322593

von Konsky, B. R., Ivins, J., \& Gribble, S. J. (2009). Lecture attendance and web based lecture technologies: A comparison of student perceptions and usage patterns. Australasian Journal of Educational Technology, 25(4), 581-595. http:/ / www.ascilite.org.au/ajet/ ajet25/vonkonsky.html

Williams, A., Birch, E. \& Hancock, P. (2012). The impact of online lecture recordings on student performance. Australasian Journal of Educational Technology, 28(2), 199-213. http: / / www.ascilite.org.au/ajet/ajet28/williams.html 


\section{Appendix: Preliminary questionnaire}

Overarching question

"How would you rate the following functionalities in a recording system on the following scale: 1 (not important), 2 (of little importance), 3 (neutral), 4 (somewhat important), 5 (very important)?"

\begin{tabular}{|c|c|c|c|c|c|}
\hline \multirow{2}{*}{\multicolumn{6}{|c|}{\begin{tabular}{|l|}
\multicolumn{1}{|c|}{ Functionalities } \\
$\begin{array}{l}\text { Broadcast/stream the session (e.g. to another room) while } \\
\text { delivering/recording it }\end{array}$
\end{tabular}}} \\
\hline & & & & & \\
\hline Capture student discussion in the recording (e.g. with roving microphone) & & & & & \\
\hline See the presenter's "talking head" in the recording (along with the audio) & & & & & \\
\hline See whatever is being presented on screen in the recording (with the audio) & & & & & \\
\hline $\begin{array}{l}\text { Visual indicator of whether the microphone is working and ability to set the } \\
\text { volume level of the microphone }\end{array}$ & & & & & \\
\hline Schedule recordings in advance & & & & & \\
\hline Start and stop recording when you want & & & & & \\
\hline Pause the recording & & & & & \\
\hline Make recordings from your office, home or out in the field & & & & & \\
\hline $\begin{array}{l}\text { Chop off the beginning and ending of the recording before making it } \\
\text { available to students }\end{array}$ & & & & & \\
\hline Edit any part of the recording before making it available to students & & & & & \\
\hline Set dates after/between which the recording is available to students & & & & & \\
\hline Integration with BlackBoard & & & & & \\
\hline $\begin{array}{l}\text { Integration with mobile devices (e.g. watch on different mobile platforms, } \\
\text { notification of availability of new recordings) }\end{array}$ & & & & & \\
\hline Students can use the same system to create their own recordings & & & & & \\
\hline $\begin{array}{l}\text { Quickly and easily annotate/scribble over the top of whatever you are } \\
\text { showing on the screen }\end{array}$ & & & & & \\
\hline $\begin{array}{l}\text { Use a built-in whiteboard to draw, write equations, etc., without using other } \\
\text { hardware }\end{array}$ & & & & & \\
\hline Attach supplementary documentation (e.g. PDF) to the recording & & & & & \\
\hline Automatically chapterise recordings using thumbnails & & & & & \\
\hline Search recordings for words in any of the text that appears on the screen & & & & & \\
\hline Search recordings for words that are only spoken & & & & & \\
\hline Set bookmarks in the recording to highlight key points to the entire class & & & & & \\
\hline $\begin{array}{l}\text { See bookmarks set by students that show what they consider to be } \\
\text { "important", "unclear" or where they have made a "comment" on the } \\
\text { recording }\end{array}$ & & & & & \\
\hline $\begin{array}{l}\text { Easily pinpoint a moment in time in a recording and push that to others so } \\
\text { that it can be discussed further. }\end{array}$ & & & & & \\
\hline Play back the recording at a different speed (0.7x to $2 \mathrm{x})$ & & & & & \\
\hline Print thumbnails of the slides (including annotations) & & & & & \\
\hline Easily obtain usage statistics for & & & & & \\
\hline
\end{tabular}

Author: Dr Lisa Germany, Educational Manager e-Learning

Office of the PVC Learning and Teaching, Victoria University, Melbourne, Australia

Email: Lisa.Germany@vu.edu.au

(formerly at Swinburne University of Technology)

Please cite as: Germany, L. (2012). Beyond lecture capture: What teaching staff want from web-based lecture technologies. Australasian Journal of Educational Technology, 28(7), 1208-1220. http: / / www.ascilite.org.au/ajet/ajet28/germany.html 